\title{
Infrared Repair Brazing of 403 Stainless Steel with a Nickel- Based Braze Alloy
}

\begin{abstract}
R.K. SHIUE, S.K. WU, and C.M. HUNG
Martensitic stainless steel (403SS) is extensively used for intermediate and low-pressure steam turbine blades in fossil-fuel power plants. The purpose of this investigation is to study the repair of shallow cracks on the surface of 403SS steam turbine blades by infrared repair brazing using rapid thermal cycles. A nickel-based braze alloy (NICROBRAZ LM) is used as filler metal. The braze alloy after brazing is primarily comprised of borides and an $\mathrm{FeNi}_{3}$ matrix with different amounts of alloying elements, especially $\mathrm{B}$ and $\mathrm{Si}$. As the brazing temperature increases, more Fe atoms are dissolved into the molten braze. Some boron atoms diffuse into the 403SS substrate primarily via grain boundary diffusion and form B-Cr-Fe intermetallic precipitates along the grain boundaries. The LM filler metal demonstrates better performance than 403SS in both microhardness and wear tests. It is also noted that specimens brazed in a vacuum have less porosity than those brazed in an Ar atmosphere. The shear strength of the joint is around $300 \mathrm{MPa}$ except for specimens brazed in short time periods, e.g., 5 seconds in Ar flow and 30 seconds in vacuum. The fractographs mainly consist of brittle fractures and no ductile dimple fractures observed in the scanning electron microscope (SEM) examination.
\end{abstract}

\section{INTRODUCTION}

MARTENSITIC stainless steel is widely used for intermediate- and low-pressure steam turbine blades in fossilfuel power plants due to its good creep strength and moderate corrosion resistance. ${ }^{[1-5]}$ The successful application of martensitic stainless steels in steam turbine blades is worldwide. ${ }^{[2,6]}$ Currently, intermediate- and low-pressure steam turbine blades in a fossil power plant are made of 403 stainless steel. Many researchers have focused on the mechanical properties, fatigue resistance, and corrosion resistance of 403 stainless steels. ${ }^{[7-20]}$ However, most of these studies are limited to traditional processing technology. This current research investigates a new technique, infrared repair brazing.

For 403 low-pressure steam turbine blades, cracks can initiate and grow on the surface of blades due to the erosion of high-speed water droplets condensed from supersaturated steam after long-term operation, seriously jeopardizing the steam turbine safety. Repair welding of 403 stainless-steel turbine blades is one of the most common methods used to fix such cracks, and the welding of 403 stainless steels is a well-developed technique. ${ }^{[21,22,23]}$ However, the repair welding of shallow cracks on the tips of low-pressure turbine blades is not the only choice. Infrared repair brazing of surface shallow cracks, e.g., less than $1 \mathrm{~mm}$ in depth, is an alternative method to fix such blades. Therefore, both techniques are complementary to each other.

Infrared brazing makes use of infrared energy generated by heating a tungsten filament in a quartz tube as the heating

R.K. SHIUE, Associate Professor, is with the Institute of Materials Science and Engineering, National Dong Hwa University, Hualien 974, Taiwan, Republic of China. S.K. WU, Professor, is with the Department of Materials Science and Engineering, National Taiwan University, Taipei 106, Taiwan, Republic of China. C.M. HUNG, former Graduate Student, is with the Institute of Mechanical Engineering, National Taiwan University, Taipei 106, Taiwan, Republic of China. Contact e-mail: skw@ccms.ntu.edu.tw

Manuscript submitted September 11, 2001. source, providing a rapid heating rate of up to $3000{ }^{\circ} \mathrm{C} /$ min..$^{[24-27]}$ This is important, since a fast brazing thermal cycle is necessary to avoid liquation of the braze alloy. ${ }^{[28,29]}$ For a brazing filler alloy with different solidus and liquidus temperatures, the composition of the melt will gradually change as the temperature increases from the solidus to liquidus. ${ }^{[28]}$ If the portion that melts first is allowed to flow out, the remaining solid may not melt and may remain behind as a residue, which is called liquation. ${ }^{[28]}$ Filler alloys with narrow melting ranges do not tend to liquation, so they flow quite freely into joints with narrow clearance. On the other hand, a filler metal with a wide melting range needs rapid heating cycles to minimize separation during brazing. It is also noted that most interfacial reactions between the base metal and braze alloy can be inhibited or delayed by using a rapid brazing cycle. ${ }^{[30]}$ Thus, a fast thermal cycle is crucial for certain braze alloys having large melting ranges.

The infrared rays can easily transmit through the quartz tube and not be absorbed by the quartz furnace itself. Using an appropriate optical focusing system, local heating of the bonding surfaces can be obtained. Therefore, infrared brazing is characterized by both high-speed thermal cycles and high-energy efficiency, making it very promising for joining processes. ${ }^{[24,25]}$ The purpose of this investigation is to study the repair of shallow cracks on the surface of low-pressure turbine blades by infrared brazing. A nickel-based braze alloy, NICROBRAZ* LM, was used as filler metal. Both

*NICROBRAZ is a trademark of Wall Colmonoy Co., Michigan 48071.

the microstructural evolution and shear strength of the brazed joint are evaluated.

\section{EXPERIMENTAL PROCEDURE}

There are many commercially available high-temperature nickel-based brazing filler alloys, as displayed in Table I. Both NICROBRAZ 10 and NICROBRAZ 50 have low melting points, but phosphorus is included in their chemical composition. It is reported that phosphorus-containing filler metals suffer from low ductility because they form nickel phosphides. ${ }^{[28]}$ Therefore, phosphorus-containing filler 
Table I. Commercially Available High-Temperature Brazing Filler Alloys

\begin{tabular}{clc}
\hline NICROBRAZ & $\begin{array}{c}\text { Nominal Composition } \\
\text { (Wt Pct) }\end{array}$ & $\begin{array}{c}\text { Melting Point }\left({ }^{\circ} \mathrm{C}\right) \\
\text { Solidus/Liquidus }\end{array}$ \\
\hline LM & $\begin{array}{c}\text { 7Cr-3.1B-4.5Si-3Fe- } \\
\text { Ni (balance) }\end{array}$ & $970 / 1000$ \\
& 11P-Ni (balance) & $875 / 875$ \\
10 & $\begin{array}{c}\text { 19Cr-10.2Si-Ni } \\
\text { (balance) }\end{array}$ & $1080 / 1135$ \\
50 & $\begin{array}{c}\text { 14Cr-10P-Ni (balance) } \\
\text { 15Cr-3.5B-Ni } \\
\text { (balance) }\end{array}$ & $890 / 890$ \\
150 & & $1055 / 1055$ \\
&
\end{tabular}

alloys are not suitable in the turbine blade application. It is expected that the distortion of turbine blades during brazing can be minimized by using a lower brazing temperature. NICROBRAZ LM has the lowest liquidus temperature among NICROBRAZ 30, 150, and LM alloys. Although there is a difference between the solidus and liquidus temperatures of NICROBRAZ LM filler, the advantage of rapid heating during infrared brazing can prevent liquation. Additionally, there is also a difference in $\mathrm{Cr}$ content between NICROBRAZ LM and 403 stainless steel. Corrosion of low-pressure steam turbine blades is not a primary problem because purified water is always used in the steam turbine. The corrosion resistance of a nickel-based alloy is usually much better than that of 403SS. Consequently, NICROBRAZ LM filler metal was chosen in the experiment.

The base metal used in the experiment was 403SS in the form of $15 \times 15 \times 3 \mathrm{~mm}$ samples. Its chemical composition in weight percent was $0.15 \mathrm{C}, 12.0 \mathrm{Cr}, 1.0 \mathrm{Mn}, 0.5 \mathrm{Si}, 0.01 \mathrm{P}$, $0.01 \mathrm{~S}$, and the balance Fe. The 403SS surface was first polished with $\mathrm{SiC}$ paper and then an ultrasonic bath, using acetone as the solvent to clean specimens prior to infrared brazing. A nickel-based filler alloy, NICROBRAZ LM, containing in weight percent $7.0 \mathrm{Cr}, 3.1 \mathrm{~B}, 4.5 \mathrm{Si}, 3.0 \mathrm{Fe}$, and $\mathrm{Ni}$ balance and made by Wall Colmonoy Co., was used as the brazing filler alloy. Based on the American Welding Society specification for Ni-based braze alloys, the chemical composition of NICROBRAZ LM braze is consistent with BNi-2 braze. ${ }^{[22]}$ The braze alloy was in powder form with a particle size below $44 \mu \mathrm{m}$. An S-type binder made by Wall Colmonoy Co. was used in the experiment. The nickel-based alloy powder was uniformly mixed with the S-type binder in a weight ratio of $4: 1$ in order to form a paste. All specimens were dried in an oven at $100{ }^{\circ} \mathrm{C}$ for at least 1 hour prior to infrared brazing. The thickness of the braze alloy paste was manually deposited on the specimen with a thickness of about $200 \mu \mathrm{m}$ prior to brazing. After infrared brazing, the binder will be evaporated, and the braze alloy powder is consolidated into a sound joint. The width of the brazement after infrared brazing is varied between 40 and $120 \mu \mathrm{m}$.

To enhance the absorption of infrared rays, a graphite fixture was used during brazing, as shown in Figure 1. Figure 1(a) shows samples prepared for metallographic observation. Specimens were sandwiched between two graphite plates, and a thermocouple was inserted into the upper graphite plate to make contact with the 403SS specimen. There is a time delay between the actual specimen temperature and programmed temperature, as discussed in a previous study. ${ }^{[27]}$ The time delay will have a strong effect

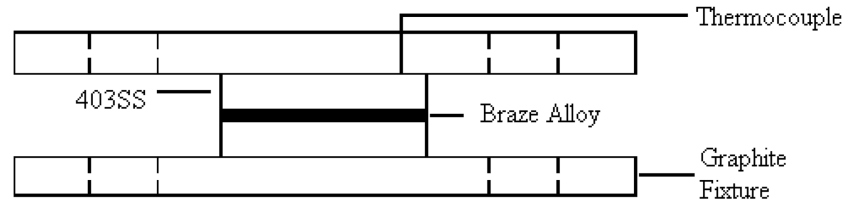

(a)

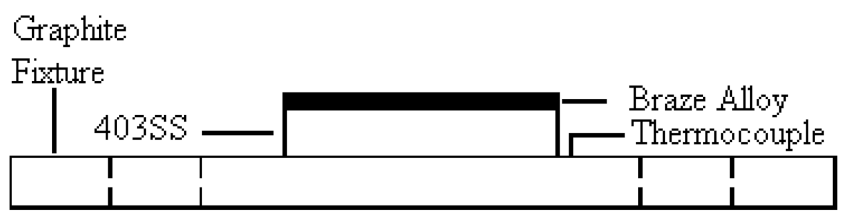

(b)

Fig. 1-Schematic diagrams showing the geometry of infrared brazed specimens used in the experiment: $(a)$ metallographic observation and $(b) \mathrm{X}$ ray analysis and wear test.

in the test if the brazing time is short ( $<5$ seconds). Therefore, time compensation during the infrared brazing was included for all specimens in the study in order to prevent incomplete melting of the braze alloy. In other words, the brazing time stands for the time period after the specimen reaches the brazing temperature. Infrared brazing was performed either in an Ar atmosphere with a flow rate of $200 \mathrm{~cm}^{3} / \mathrm{min}$ or in a vacuum of $5 \times 10^{-3} \mathrm{~Pa}$ at various temperatures for a 5 to 300 -second duration. The process variables used for NICROBRAZ LM filler metal are shown in Table II. The heating rate of the infrared furnace was set at $3000{ }^{\circ} \mathrm{C} / \mathrm{min}$ throughout the experiment.

The brazed specimens were first cut by a low-speed diamond saw, followed by a standard metallographic procedure. The polished cross section of the brazed specimens was first examined using a PHILIPS* XL30 scanning electron

*PHILIPS is a registered trademark of Philips Electronic Instruments Corp., Mahwah, NJ.

microscope (SEM) with an accelerating voltage of $15 \mathrm{kV}$. Quantitative chemical analysis was performed using a JEOL* JXL-8800M electron probe microanalyzer (EPMA)

*JEOL is a trademark of Japan Electron Optics, Ltd., Tokyo.

with an operation voltage of $15 \mathrm{kV}$ and spot size of $1 \mu \mathrm{m}$. Microhardness measurements were made using a microhardness tester (Akashi MVK-E (Akashi Co., Yokohama, Japan)) with a load of $200 \mathrm{~g}$ and a duration time 15 seconds. The structure analysis of the joint after brazing was performed using a PHILIPS PW1710 X-ray diffractometer. $\mathrm{Cu} K_{\alpha}$ was selected for the X-ray source. Figure 1(b) shows the sample prepared for the X-ray analysis and wear test. The thickness of the braze alloy paste was manually deposited on the specimen with a thickness of about $200 \mu \mathrm{m}$ prior to brazing.

Wear testing was performed using a TE77 high-frequency reciprocal wear test machine made by Cameron-Plint Tribology, Ltd. (Plint \& Partners Ltd., Old Station Business Park, Compton Berkshire, England). A schematic diagram of the wear test is shown in Figure 2. The large specimen in Figure 2 is the surface of the braze alloy, and the small specimen, a 6-mm-diameter steel bearing ball with a Rockwell hardness of 62, is the counterpart of the large specimen in the wear test. The test was under $150-\mathrm{N}$ normal load with no lubricant and $5-\mathrm{Hz}$ reciprocal frequency of the moving arm for 10 minutes. Surface morphology of the wear region 
Table II. The Process Variables Used for NICROBRAZ LM Filler Metal

\begin{tabular}{cccccccccccc}
\hline Second(s) & 5 & 10 & 15 & 20 & 25 & 30 & 45 & 60 & 90 & 120 & 180 \\
\hline $1050{ }^{\circ} \mathrm{C}$ (Ar flow) & $\mathrm{O}$ & & & & & $\mathrm{O}$ & & $\mathrm{O}$ & & & \\
$1100^{\circ} \mathrm{C}$ (Ar flow) & $\mathrm{O}$ & $\mathrm{O}$ & $\mathrm{O}$ & $\mathrm{O}$ & $\mathrm{O}$ & $\mathrm{O}$ & $\mathrm{O}$ & $\mathrm{O}$ & $\mathrm{O}$ & $\mathrm{O}$ & $\mathrm{O}$ \\
$1150^{\circ} \mathrm{C}$ (Ar flow) & $\mathrm{O}$ & & & & & $\mathrm{O}$ & & $\mathrm{O}$ & $\mathrm{O}$ \\
$1100^{\circ} \mathrm{C}$ (vacuum) & & & & & & $\mathrm{O}$ & & $\mathrm{O}$ & $\mathrm{O}$ & $\mathrm{O}$ & \\
\hline
\end{tabular}

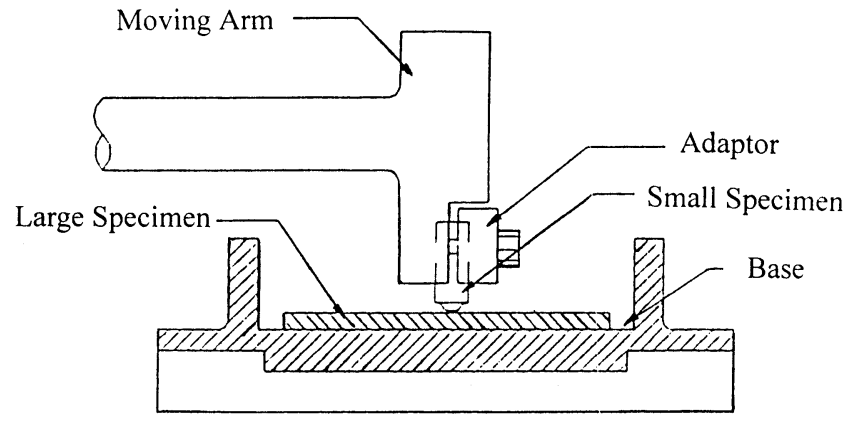

Fig. 2-A schematic diagram of the wear test layout.

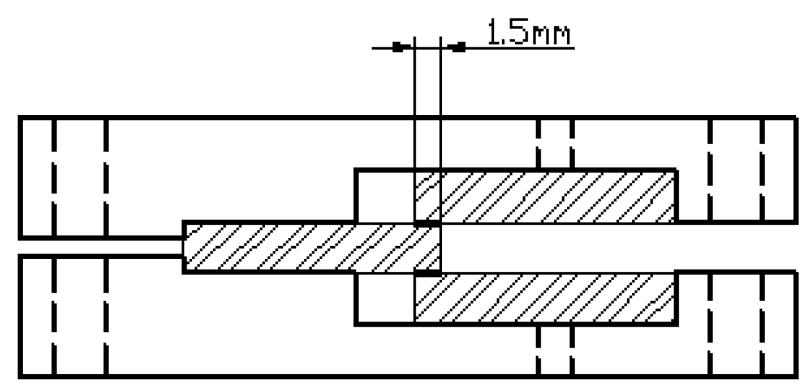

Fig. 3-A schematic diagram of the specimen used in the shear test.

after wear testing was recorded by a Hommel Werke LV150 surface profilometer (Hommel American, New Britain, CT). Finally, a shear test was performed to evaluate the bonding strength between the braze filler alloy and 403SS. Figure 3 shows a schematic diagram of the specimen used in the shear test. The shaded area is 403SS, and the outer part of the layout is the graphite fixture used in the infrared brazing furnace. The two bold black lines, $1.5-\mathrm{mm}$ wide in the middle of the graph, represent the braze filler alloy. The brazed specimen was compressed by a universal testing machine with a constant speed of $1 \mathrm{~mm} / \mathrm{min}$.

\section{RESULTS AND DISCUSSIONS}

\section{A. Microstructural Observations of the Infrared Brazed Joint}

Figure 4 shows the SEM backscattered image of NICROBRAZ LM brazed at $1100{ }^{\circ} \mathrm{C}$ for 5, 20, 90, and 300 seconds. The backscattered image does not provide topographic contrast but primarily shows the element distribution in the joint. ${ }^{[31]}$ Thus, the specimen areas containing high-atomic number elements appear light, while areas with low-atomic number elements appear dark. Based on this information, it is clear that the distribution of elements in the joint is not uniform, especially for the 5-second specimen. Since infrared brazing features rapid heating and cooling thermal cycles, the phases in the braze may be not in equilibrium for very short brazing times. When increasing the brazing time, the phases in the matrix of the braze alloy approach to equilibrium, as displayed in Figure 4(d).

Figure 5 shows the SEM backscattered images of NICROBRAZ LM after brazing at $1050{ }^{\circ} \mathrm{C}$ and $1150{ }^{\circ} \mathrm{C}$, respectively. The difference in width of the braze alloy after infrared brazing resulted from manually depositing braze alloy paste during the experiment. It is clear that the inhomogeneous microstructure of the braze processed at $1050{ }^{\circ} \mathrm{C}$, as displayed in the backscattered images, is more prominent than that brazed at $1150{ }^{\circ} \mathrm{C}$. For specimens brazed at 1050 ${ }^{\circ} \mathrm{C}$, the composition is not approaching equilibrium until the brazing time exceeds 60 seconds. Meanwhile, the equilibrium of the matrix in the braze is evident as the brazing temperature is increased to $1150{ }^{\circ} \mathrm{C}$. However, the black phase in the braze is coarsened if the brazing time exceeds 60 seconds.

Figure 6 shows the chemical analysis of various phases in the joint brazed at $1100{ }^{\circ} \mathrm{C}$ for 120 seconds, which has a stable microstructure. At least three phases with different chemical compositions are observed in the joint, including chromium boride (marked by 1 in Figure 6), matrix phase (marked by 2 and 3 in Figure 6), and interfacial precipitates (marked by 4 in Figure 6). The X-ray microanalysis shows that Region 2 has some B while Region 3 does not; yet, the two regions appear identical microstructurally. It is possible that there is a $\mathrm{CrB}$ particle below the surface of Region 2, causing the B peak in the spectrum. Consequently, one matrix phase is considered in the figure. To elucidate the microstructural evolution in the brazed joint, phase diagrams, especially those of multicomponent systems, are very helpful. The chemical composition of the LM braze in atomic percent is $6.6 \mathrm{Cr}, 14.1 \mathrm{~B}, 7.9 \mathrm{Si}, 2.6 \mathrm{Fe}$, and $\mathrm{Ni}$ balance, and the 403 stainless steel is primarily comprised of $\mathrm{Fe}$ and $\mathrm{Cr}$. A quinary equilibrium phase diagram is preferred in the study, but there is no such phase diagram currently available. Some important information can, however, be obtained with the aid of certain ternary phase diagram.

Figure 7 displays the liquidus projection of the $\mathrm{B}-\mathrm{Cr}-\mathrm{Ni}$ ternary alloy phase diagram in atomic percent, and some important invariant reactions are also included in the figure. Although $\mathrm{Si}$ is not included in the B-Cr-Ni ternary alloy phase diagram, the diagram can still provide an approximation of the phase evolution during brazing. According to Figure 7 , there are three ternary-eutectic reactions, $E_{1}, E_{2}$, and $E_{3}$, in the diagram. The chemical composition of the eutectic liquid at $E_{2}$ is close to that of the LM braze alloy. The ternary-eutectic temperature at $E_{2}$ in the B-Cr-Ni phase diagram is $1050{ }^{\circ} \mathrm{C}$. Three phases are formed during eutectic solidification, including $\mathrm{BCr}, \mathrm{BNi}_{3}$, and fcc $\mathrm{Ni}$ phase alloyed with other elements.

It was previously reported that chromium borides were 


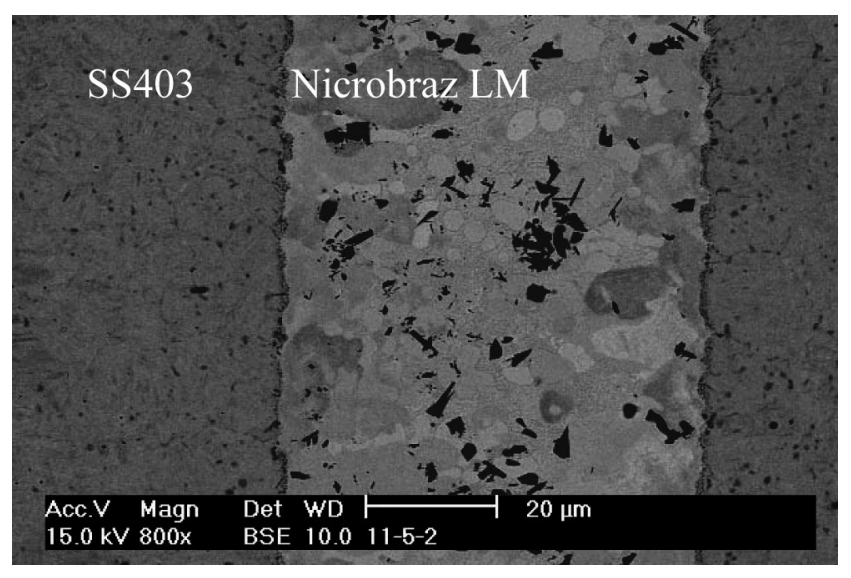

(a)

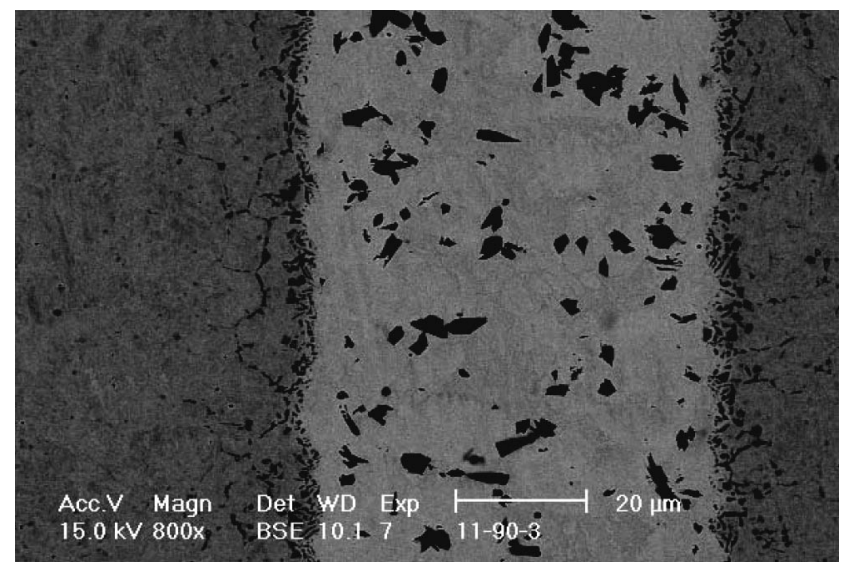

(c)

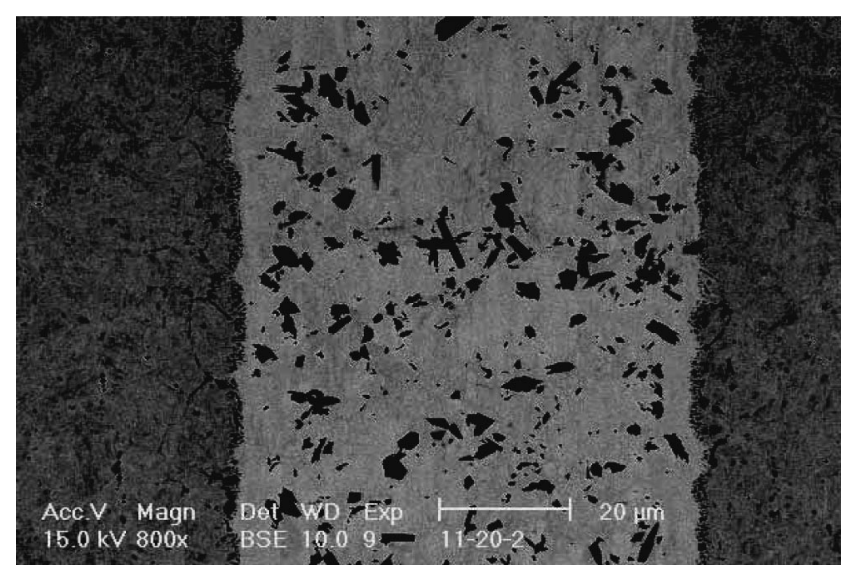

(b)

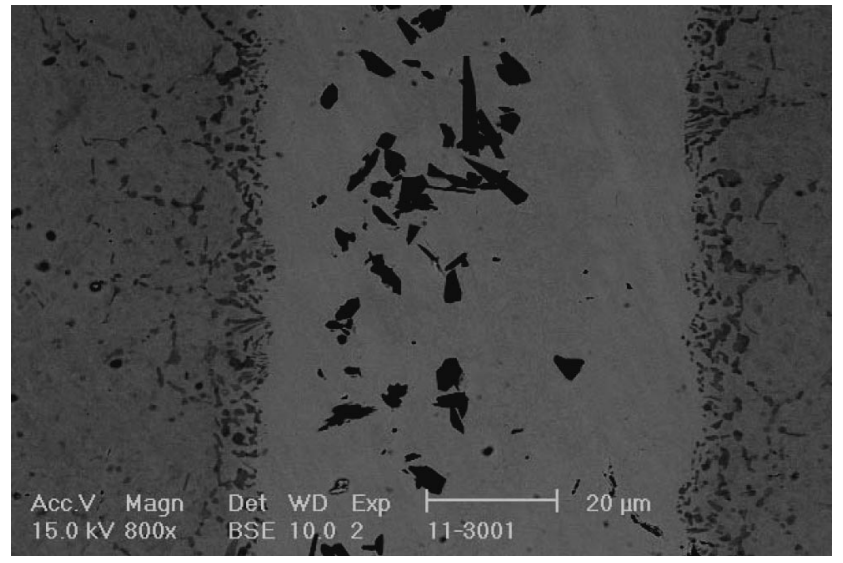

(d)

Fig. 4-The SEM backscattered image of NICROBRAZ LM brazed at $1100{ }^{\circ} \mathrm{C}$ for $(a) 5 \mathrm{~s},(b) 20 \mathrm{~s},(c) 90 \mathrm{~s}$, and $(d) 300 \mathrm{~s}$.

observed in the nickel-based braze alloy. ${ }^{[33]}$ According to the EPMA analysis of point 1 shown in Figure 6, the stoichiometry of the chromium boride phase is close to BCr. This is consistent with many other reports. ${ }^{[33-36]}$ The matrix phase is mainly comprised of $\mathrm{Ni}$ in the braze with various amounts of other alloying elements. It is also noted that the matrix phase contains Fe dissolved from the 403SS substrate. The dissolution of Fe from the 403SS substrate into the molten braze may result in isothermal solidification of the LM braze alloy during brazing. Meanwhile, very limited oxygen is detected in the EPMA analysis, indicating that there is little oxidation during infrared brazing.

Figure 8 shows the X-ray diffraction (XRD) analysis of NICROBRAZ LM brazed at $1100{ }^{\circ} \mathrm{C}$ for different time periods. The XRD data features many unidentified peaks for specimens brazed within 30 seconds, indicating that phases in the braze are fairly complex. As the brazing time increases, the phase in the braze becomes stable. Meanwhile, it is noted that only $\mathrm{FeNi}_{3}$ phase can be identified in the figure, and all other phases are not identified in the analysis. This is because the amount of the other phases is not sufficient to generate a strong enough peak in the XRD analysis. The lack of second-phase peaks in Figure 8 could be resulted from the X-ray analyzed surface of the specimen. According to Figure 1(b), only the very top surface of the braze alloy was examined by the X-ray analysis. However, it is possible that not all phases existed on the top surface of the sample.
For example, very few $\mathrm{CrB}$ phases are observed at the interface between the braze and 403SS, as shown in Figures 4(c) and (d). Therefore, it is reasonable that only $\mathrm{FeNi}_{3}$ phase was identified in the analysis even for the 90 -second brazed specimen. The $\mathrm{FeNi}_{3}$ phase is observed throughout the experiment even for the specimen brazed at $1100{ }^{\circ} \mathrm{C}$ for 5 seconds. Based on both XRD and EPMA analysis, the matrix of the braze after infrared brazing is mainly comprised of $\mathrm{FeNi}_{3}$ phase alloyed with many other elements, e.g., B, Cr, Si, etc.

There is no reaction layer between the LM braze and 403SS, but a black dot phase at the interface between 403SS and NICROBRAZ LM is observed, as shown in Figures 4 through 6. Based on EPMA analysis of point 4, shown in Figure 6, the black dot phase is primarily comprised of $\mathrm{B}$, $\mathrm{Cr}$, and $\mathrm{Fe}$. It has been reported that $\mathrm{B}$ in the braze will readily diffuse into the base metal and form intermetallics along grain boundaries of the base metal. ${ }^{[33]}$ This is consistent with our experimental results. The boron atoms diffuse into 403SS base metal primarily via grain boundary diffusion and form $\mathrm{B}-\mathrm{Cr}-\mathrm{Fe}$ intermetallic phase particles along the grain boundaries of the base metal close to the joint interface. Although the ternary $\mathrm{B}-\mathrm{Cr}-\mathrm{Fe}$ phase diagram is not complete, six ternary phases, $\mathrm{BCrFe}, \mathrm{B}_{33} \mathrm{Cr}_{13} \mathrm{Fe}_{54}$, $\mathrm{B}_{33} \mathrm{Cr}_{33} \mathrm{Fe}_{34}, \mathrm{~B}_{38} \mathrm{Cr}_{55} \mathrm{Fe}_{7}, \mathrm{~B}_{50} \mathrm{Cr}_{20} \mathrm{Fe}_{30}$, and $\mathrm{B}_{50} \mathrm{Cr}_{35} \mathrm{Fe}_{15}$, have been found in the diagram. ${ }^{[32]}$ However, the size of the $\mathrm{B}$ $\mathrm{Cr}-\mathrm{Fe}$ ternary-intermetallic phase is less than $1 \mu \mathrm{m}$, which is smaller than the spot size used in the EPMA analysis. 


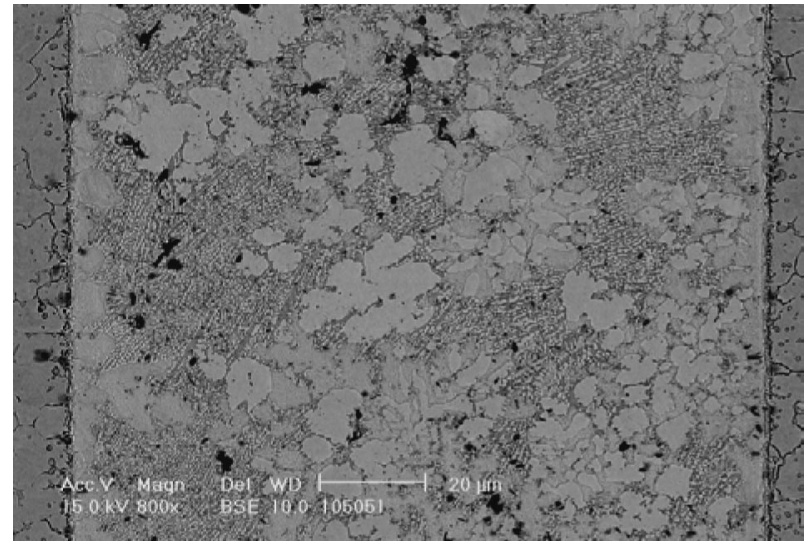

(a)

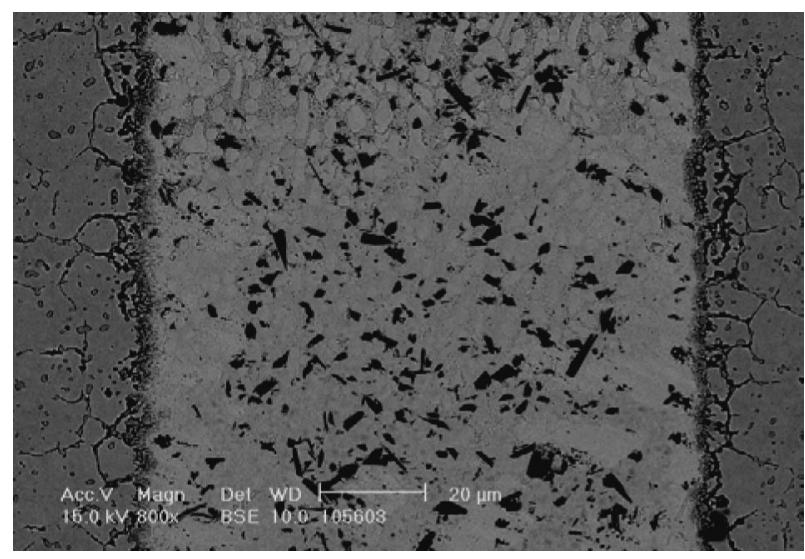

(c)



(e)

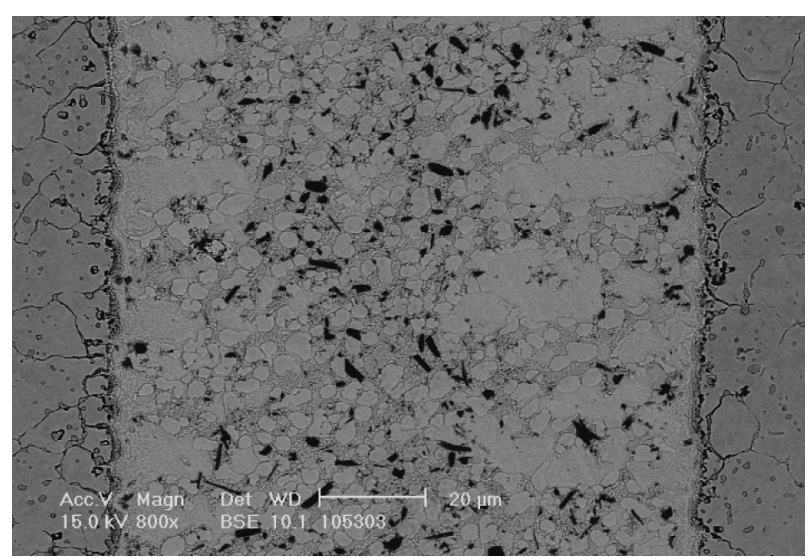

(b)

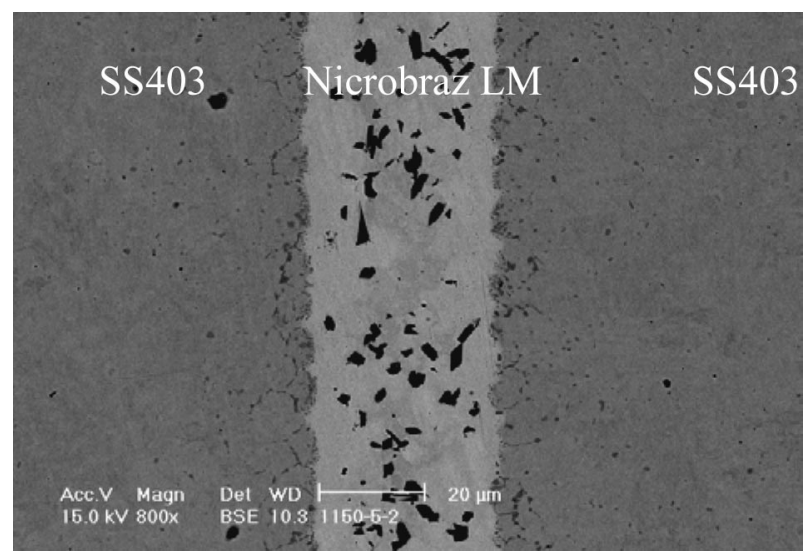

(d)

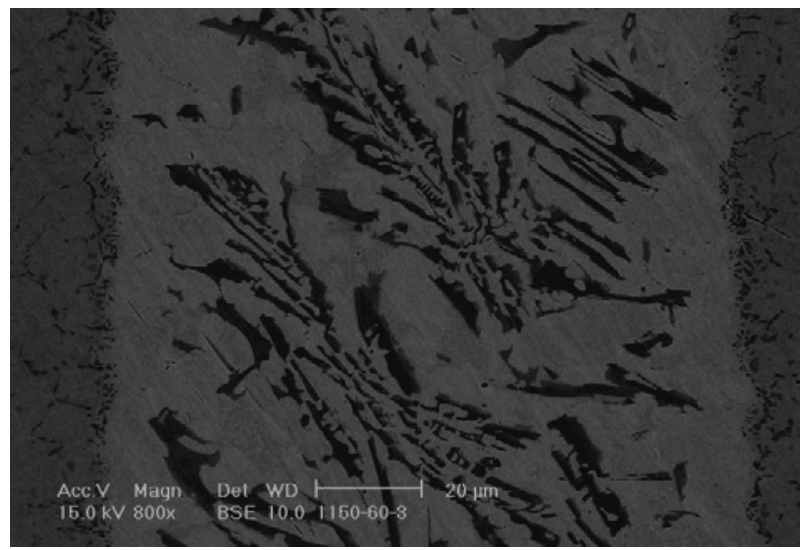

$(f)$

Fig. 5-The SEM backscattered image of NICROBRAZ LM brazed at $1050{ }^{\circ} \mathrm{C}$ for $(a) 5 \mathrm{~s},(b) 30 \mathrm{~s},(c) 60 \mathrm{~s}$, and $1150{ }^{\circ} \mathrm{C}$ for $(d) 5 \mathrm{~s}$, $(e) 30 \mathrm{~s}$, and $(f)$ $60 \mathrm{~s}$.

The analysis may also include characteristic X-rays from the 403SS substrate, so there is no precise stoichiometric compound confirmed in the study.

Figure 9 shows the chemical analysis of various phases in the joint brazed at $1150{ }^{\circ} \mathrm{C}$ for 60 seconds. As the brazing temperature increases, more $\mathrm{Fe}$ atoms are dissolved into the molten braze. The boride phase (marked by 1 in Figure 9) is now mainly comprised of $\mathrm{B}, \mathrm{Cr}, \mathrm{Fe}$, and $\mathrm{Ni}$, which is different from the EPMA analysis results for the boride displayed in Figure 6. Points 2, 3, and 4 in Figure 9 are primarily comprised of $\mathrm{Ni}$ with different alloying-element contents. The major difference in the matrix phases is their chemical contents of B and Si. Based on the XRD analysis (not shown here), the $\mathrm{FeNi}_{3}$ phase is observed to be the matrix phase for the specimens brazed at $1150{ }^{\circ} \mathrm{C}$ for 5,30 , and 60 seconds. Similar to the specimens brazed at 1100 ${ }^{\circ} \mathrm{C}$, the matrix of the braze alloy is mainly comprised of the $\mathrm{FeNi}_{3}$ phase alloyed with different amounts of $\mathrm{B}, \mathrm{Si}$, and $\mathrm{Cr}$. The chemical composition of the interfacial intermetallic precipitates is $19.9 \mathrm{~B}-1.0 \mathrm{C}-0.1 \mathrm{Si}-17.0 \mathrm{Cr}-59.9 \mathrm{Fe}-2.0 \mathrm{Ni}$ in atomic percent, which is close to those in brazes brazed at $1100{ }^{\circ} \mathrm{C}$ for 120 seconds (Figure 6). 


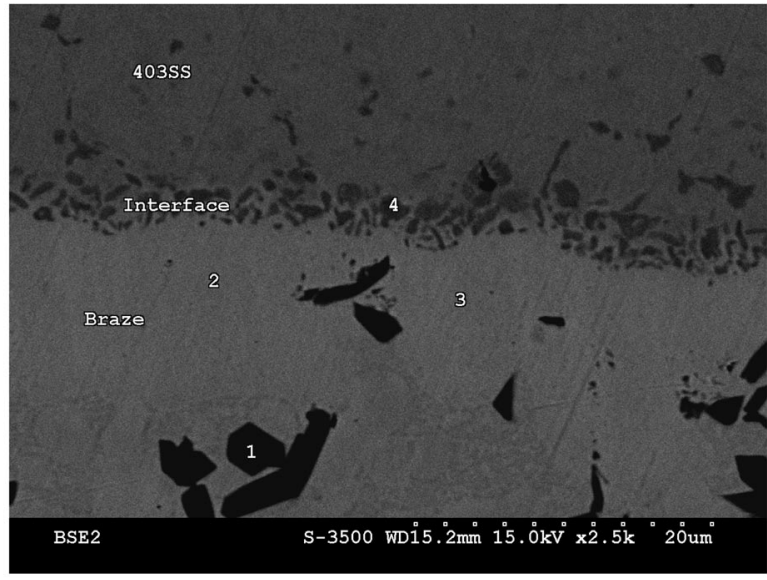

\begin{tabular}{|l|l|l|l|l|l|l|l|l|}
\hline No & \multicolumn{2}{|c|}{1} & \multicolumn{2}{c|}{2} & \multicolumn{2}{c|}{3} & \multicolumn{2}{c|}{4} \\
\hline Content & wt\% & at\% & wt\% & at\% & wt\% & at\% & wt\% & at\% \\
\hline B & 13.8 & 43.6 & 2.4 & 11.0 & --- & --- & 5.9 & 23.9 \\
\hline C & --- & --- & 0.6 & 2.5 & 0.5 & 2.5 & 0.4 & 1.5 \\
\hline $\mathrm{O}$ & --- & --- & 0.2 & 0.5 & 0.1 & 0.3 & --- & --- \\
\hline $\mathrm{Si}$ & --- & --- & 2.2 & 4.0 & 2.3 & 4.5 & 0.1 & 0.2 \\
\hline $\mathrm{Cr}$ & 83.1 & 54.6 & 9.2 & 8.8 & 7.9 & 8.4 & 20.2 & 17.0 \\
\hline $\mathrm{Fe}$ & 1.2 & 0.8 & 17.1 & 15.2 & 18.0 & 17.8 & 68.5 & 53.7 \\
\hline $\mathrm{Ni}$ & 1.9 & 1.0 & 68.3 & 58.0 & 71.2 & 66.6 & 4.9 & 3.7 \\
\hline
\end{tabular}

Fig. 6-The chemical analysis of phases in the joint for NICROBRAZ LM brazed at $1100{ }^{\circ} \mathrm{C}$ for $120 \mathrm{~s}$.

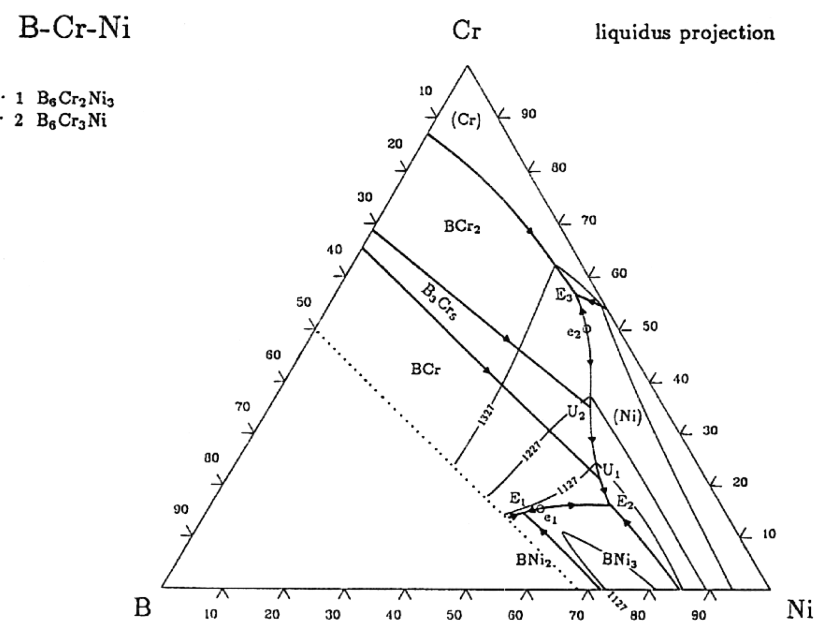

Reaction Scheme

$\mathrm{B}-\mathrm{Cr}-\mathrm{Ni}$



$1096^{\circ} \mathrm{C} \quad \mathrm{L}=35.6$ at. $\% \mathrm{~B}, 14.7$ at. $\% \mathrm{Cr}$

$\begin{array}{ll}1050^{\circ} \mathrm{C} & \mathrm{L}=18.3 \text { at. } \% \mathrm{~B}, 16.1 \text { at. } \% \mathrm{Cr} \\ 1258^{\circ} \mathrm{C} & \mathrm{L}=4.3 \text { at. \% B } 57.9 \text { at. } \% \mathrm{Cr}\end{array}$

$1258^{\circ} \mathrm{C} \quad L=4.3$ at. $\quad \mathrm{B}, 57.9 \mathrm{at} . \% \mathrm{Cr}$

$1220^{\circ} \mathrm{C} \quad \mathrm{L}=12.3$ at. $\% \mathrm{~B}, 35.3$ at. $\% \mathrm{Cr}$

Fig. 7-Liquidus projection of B-Cr-Ni ternary alloy phase diagram. ${ }^{[32]}$

\section{B. Mechanical Evaluation of the Infrared Brazed Joint}

Figure 10 shows the microhardness measurements of the braze for both $1100{ }^{\circ} \mathrm{C}$ and $1150{ }^{\circ} \mathrm{C}$ in Ar flow as well as
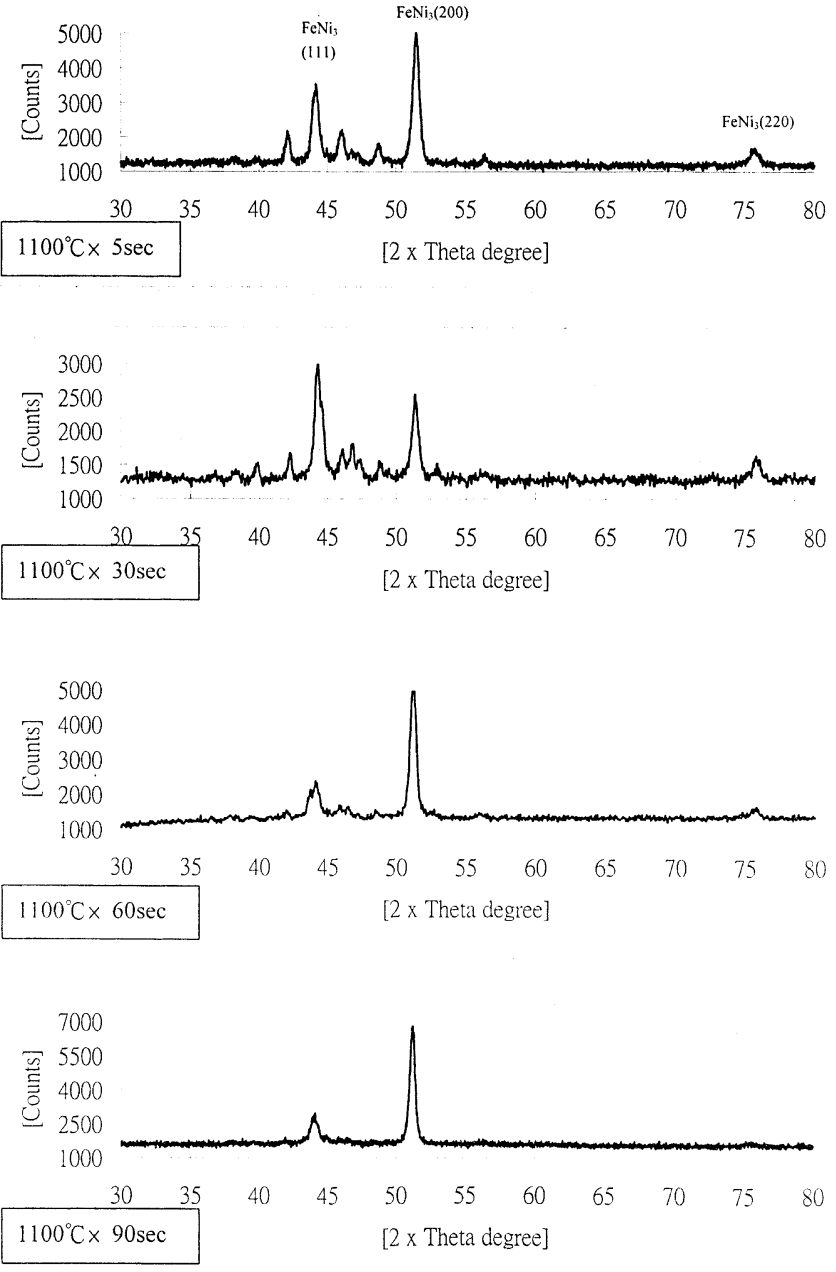

Fig. 8-The XRD analysis of NICROBRAZ LM brazed at $1100{ }^{\circ} \mathrm{C}$ for different time periods.

for $1100{ }^{\circ} \mathrm{C}$ in high vacuum. It is noted that a high hardness is obtained for specimens with short brazing times. For samples brazed in the Ar atmosphere, the hardness value levels off at $\mathrm{Hv} 540$ after 30 seconds. According to the previous analysis, it is clear that the higher hardness may result from the existence of metastable phases in the braze after solidification. As the microstructure of the braze is stabilized, its hardness remains constant. However, even higher hardness values can be found for specimens brazed under vacuum conditions because of heat transfer in a vacuum being less efficient than in an $\mathrm{Ar}$ atmosphere. The use of powder-form braze alloy is responsible for the less efficient heating in vacuum. Although the transfer of heat flux in vacuum is primarily radiant, the heat transfer from the graphite specimen holder into the braze alloy is performed via heat conduction. The actual contact area between powder particles is very limited during brazing. On the other hand, the heat transfer between the graphite specimen holder and the braze-alloy powder can be assisted by the Ar atmosphere. Consequently, infrared brazing in an $\mathrm{Ar}$ atmosphere is more efficient than that in a vacuum. It is expected that the bonding strength be deteriorated for a short-time $(<30$ seconds), vacuum-brazed specimen due to insufficient heating of the braze powder.

Figure 11 displays the wear test results of the 403SS base 


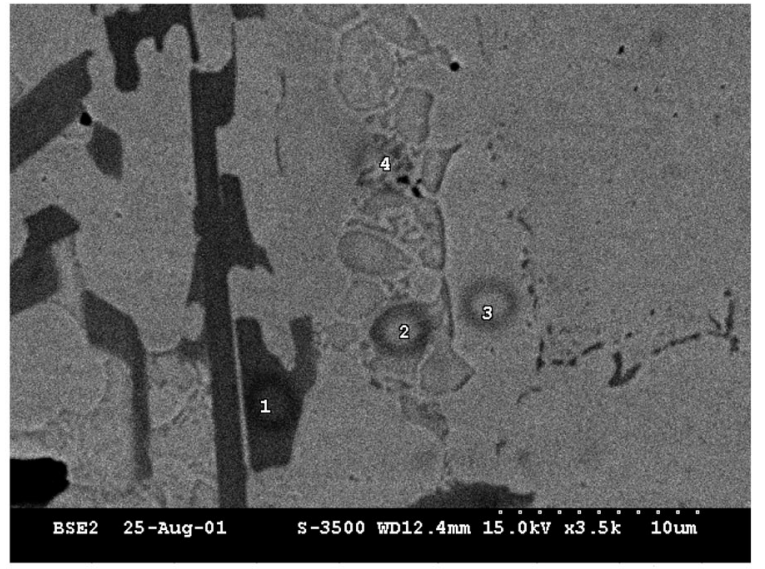

\begin{tabular}{|l|l|l|l|l|l|l|l|l|}
\hline No & \multicolumn{2}{|c|}{1} & \multicolumn{2}{c|}{2} & \multicolumn{2}{c|}{3} & \multicolumn{2}{c|}{4} \\
\hline Content & $\mathrm{wt} \%$ & $\mathrm{at} \%$ & $\mathrm{wt} \%$ & $\mathrm{at} \%$ & $\mathrm{wt} \%$ & $\mathrm{at} \%$ & $\mathrm{wt} \%$ & $\mathrm{at} \%$ \\
\hline $\mathrm{B}$ & 5.4 & 22.3 & 3.8 & 16.6 & --- & --- & 1.2 & 5.6 \\
\hline $\mathrm{C}$ & 0.4 & 1.6 & 1.3 & 5.1 & 1.0 & 4.4 & 1.1 & 4.6 \\
\hline $\mathrm{O}$ & -- & -- & 0.4 & 1.1 & 0.2 & 0.6 & 0.3 & 0.8 \\
\hline $\mathrm{Si}$ & -- & --- & 0.1 & 0.1 & 3.0 & 5.7 & 6.9 & 12.2 \\
\hline $\mathrm{Cr}$ & 31.4 & 26.9 & 3.0 & 2.7 & 3.0 & 3.1 & 1.8 & 1.7 \\
\hline $\mathrm{Fe}$ & 46.5 & 37.0 & 26.1 & 22.0 & 29.7 & 28.5 & 14.6 & 12.9 \\
\hline $\mathrm{Ni}$ & 16.2 & 12.2 & 65.3 & 52.4 & 63.1 & 57.6 & 74.0 & 62.1 \\
\hline
\end{tabular}

Fig. 9-The chemical analysis of phases in the joint for NICROBRAZ LM brazed at $1150{ }^{\circ} \mathrm{C}$ for $60 \mathrm{~s}$.

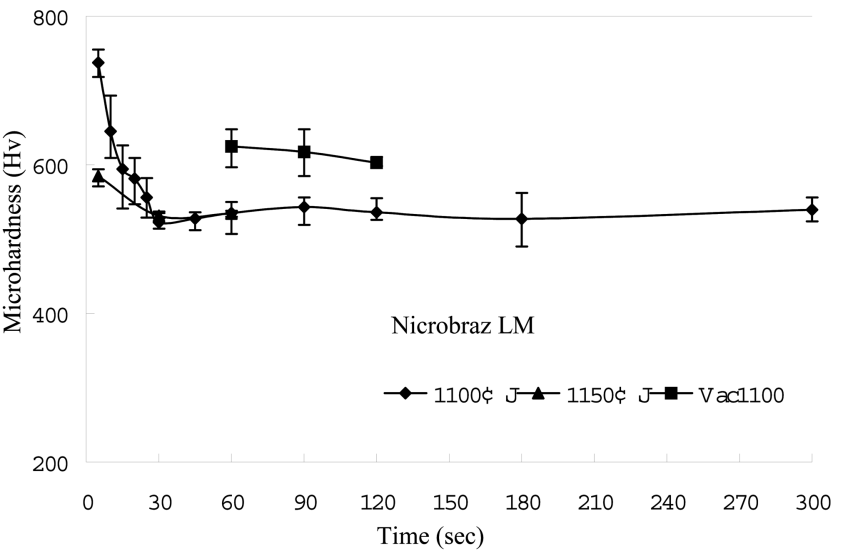

Fig. 10- The microhardness measurement of the filler alloy brazing at various temperatures.

metal and the braze alloy for different time periods of 1100 ${ }^{\circ} \mathrm{C}$. The hardness of the 403SS base metal is Hv 440, and the depth of scratch in wear test is about $200 \mu \mathrm{m}$. The scratch depth in the braze is increased with the increment of brazing time, and there was no delamination of the braze alloy observed in the test. It is consistent with the preceding microhardness measurements. In general, the harder the material, the more wear resistant it is if there is no delamination of the braze alloy in the test. According to Archard's equation, the wear resistance of a ductile material is primarily dependent upon the hardness of material. ${ }^{[37]}$ However, both hardness and toughness of the material are major factors

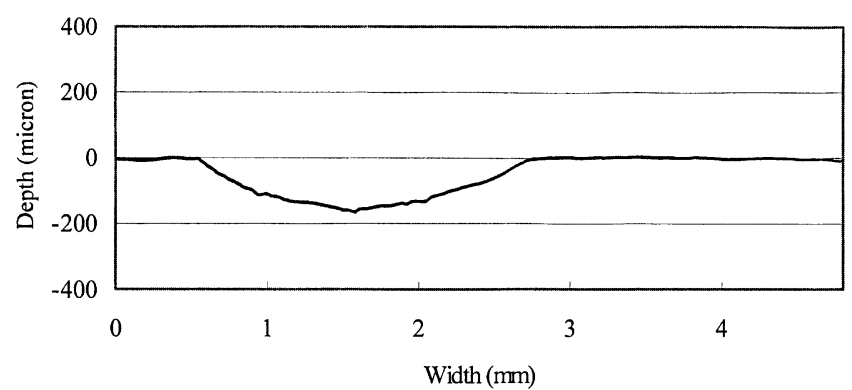

(a)

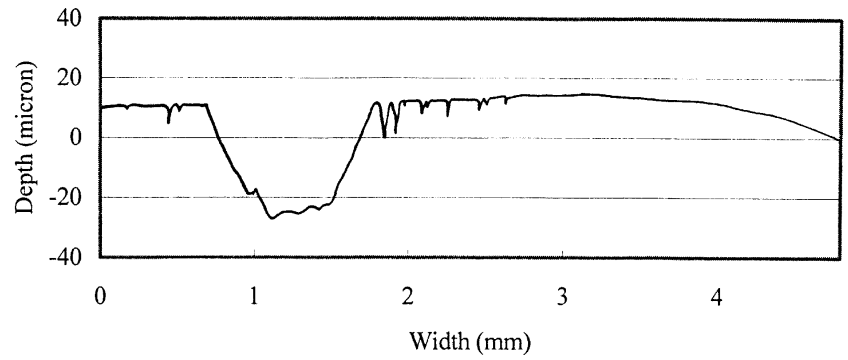

(b)

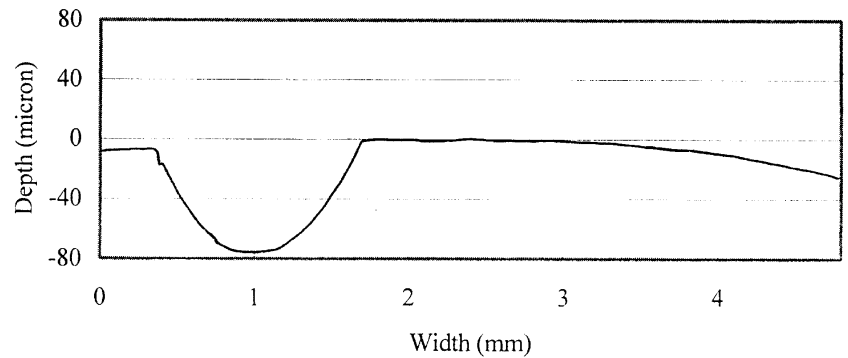

(c)

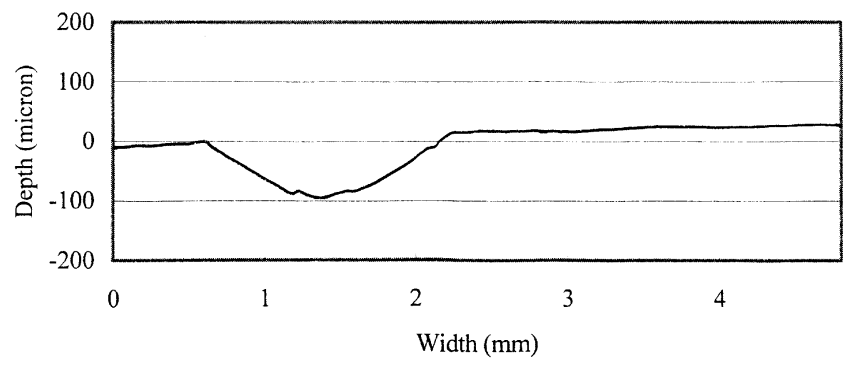

(d)

Fig. 11-The wear test results of 403SS and the braze alloy with various time periods: (a) 403SS, (b) $5 \mathrm{~s}$, (c) $30 \mathrm{~s},(d) 90 \mathrm{~s}$.

affecting the erosive behavior of the material. ${ }^{[37]}$ Therefore, neither microhardness measurements or wear-test results can exactly simulate the actual service condition of the braze alloy. Further study is necessary in order to accurately evaluate the braze alloy for a specific practical application.

Table III shows the shear test strength of the brazed joints. The bonding strength of most joints was around $300 \mathrm{MPa}$, except for specimens brazed in a short time period. Specimens brazed in less than 5 seconds under the Ar atmosphere exhibited low bonding strength. In addition, specimens brazed in a vacuum for less than 30 seconds also showed low shear strength. This low bonding strength resulted from the existence of a hard and brittle metastable phase in the alloy for short brazing times. According to the experimental 
Table III. Shear Test Results of the Brazed Joint for Various Process Variables

\begin{tabular}{cccc}
\hline \multirow{2}{*}{ Environment } & $\begin{array}{c}\text { Temperature } \\
\left({ }^{\circ} \mathrm{C}\right)\end{array}$ & $\begin{array}{c}\text { Time } \\
(\mathrm{s})\end{array}$ & $\begin{array}{c}\text { Shear stress } \\
(\mathrm{MPa})\end{array}$ \\
\hline \multirow{3}{*}{1050} & 5 & 116.0 \\
$\mathrm{Ar}$ & & 30 & 298.0 \\
& & 60 & 327.3 \\
& 1100 & 5 & 214.9 \\
& & 30 & 300.6 \\
& & 60 & 296.5 \\
& & 50 & 305.1 \\
& & 5 & 211.0 \\
Vacuum & & 30 & 289.1 \\
& & 60 & 303.4 \\
& & 30 & 265.4 \\
& & 60 & 310.2 \\
& & 90 & 317.8 \\
\hline
\end{tabular}

results for brazing in an Ar atmosphere, NICROBRAZE LM filler alloy should be infrared brazed above $1050{ }^{\circ} \mathrm{C}$ for at least 30 seconds in order to obtain optimal bonding strength. Similarly, the minimum requirement for specimens infrared brazed in a vacuum condition is $1100{ }^{\circ} \mathrm{C}$ for 60 seconds. The 403 stainless steels are usually austenitized between $925^{\circ} \mathrm{C}$ and $1010{ }^{\circ} \mathrm{C}$, using the upper end of the temperature range for larger sections or when maximum corrosion resistance and strength are required. ${ }^{[38]}$ Since infrared brazing features rapid local heating of the specimen, it is believed that brazing above $1050{ }^{\circ} \mathrm{C}$ for 60 seconds will not deteriorate the mechanical properties of the base metal.

Figure 12 shows the fractographs of specimens brazed at $1100{ }^{\circ} \mathrm{C}$ for 60 seconds under two different brazing environments, vacuum and Ar flow. It is noted that the specimen brazed in the Ar atmosphere has more porosity than that brazed in a vacuum. However, the porosity did not appear to greatly affect the bonding strength of the brazed joint in the shear test. As shown in Table III, the shear strength of the vacuum-brazed specimen at $1100{ }^{\circ} \mathrm{C}$ for 60 seconds is slightly higher than that of the Ar-brazed specimen at 1100 ${ }^{\circ} \mathrm{C}$ for 60 seconds. The trapped $\mathrm{Ar}$ atoms in the braze powder have little opportunity to be removed during infrared brazing due to the sandwich geometry of the fixture, as shown in Figure 1(a). However, the infrared repair brazing of lowpressure turbine blades is performed by depositing braze alloy paste on the surface of these blades. The trapped $\mathrm{Ar}$ atoms in the braze powder can be easily removed as the molten braze formed during infrared brazing. Consequently, porosity should not be a problem in practical application.

Figure 13 shows the SEM examination of the fracture surface of braze alloy after shear test. The fractographs indicate mainly brittle fractures (Figure 13(a)), and a few sliding facets can also be observed. The sliding facets were caused by shear force in the test. No ductile dimple fractures were observed in the SEM examination.

\section{CONCLUSIONS}

1. NICROBRAZ LM can be used in infrared brazing of 403SS. For infrared repair brazing of surface shallow cracks, e.g., less than $1 \mathrm{~mm}$ in depth, it is necessary that specimens be brazed at $1050{ }^{\circ} \mathrm{C}$ for at least 30 seconds

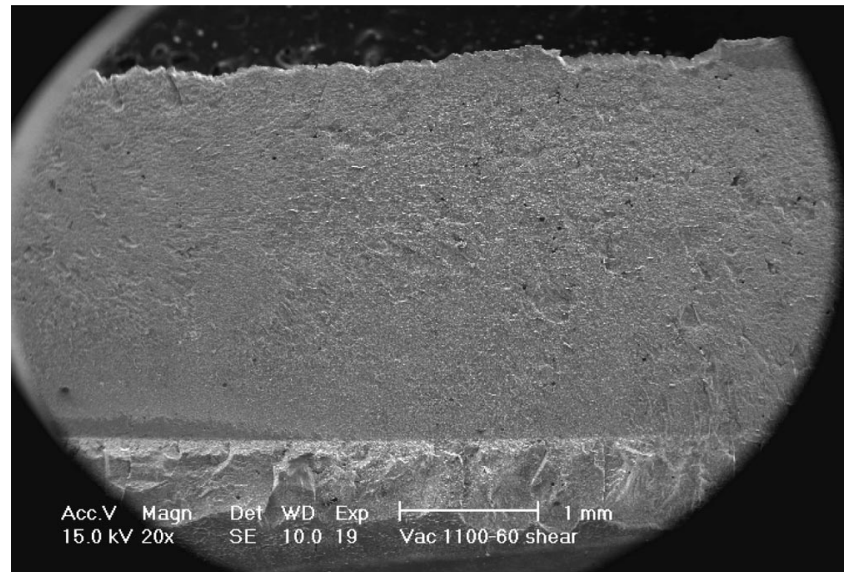

(a)

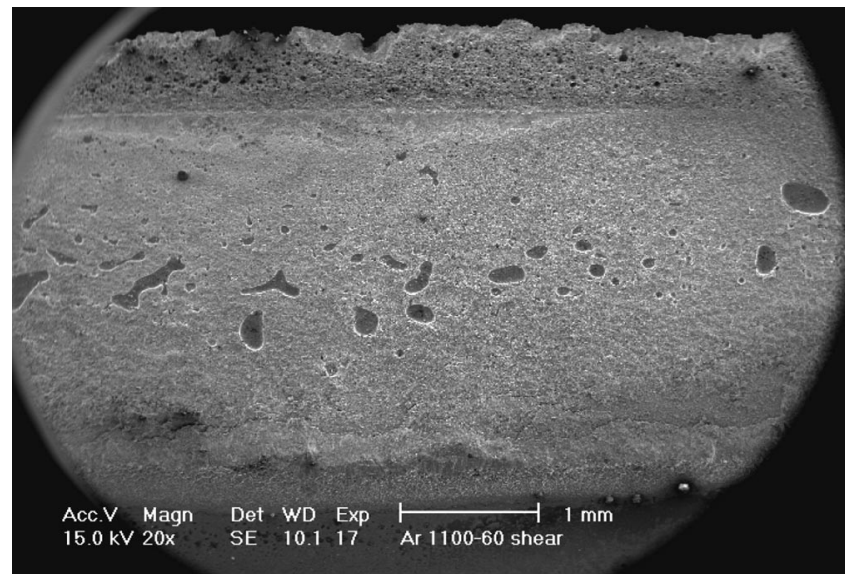

(b)

Fig. 12-The fractographs of the infrared brazed specimens at $1100{ }^{\circ} \mathrm{C}$ for 60 s after shear test: $(a)$ vacuum $(b)$ Ar environment.

in an Ar flow atmosphere in order to obtain sufficient bonding strength. Similarly, brazing at $1100{ }^{\circ} \mathrm{C}$ for at least 60 seconds is the minimum requirement for vacuum infrared brazing. Specimens brazed in a vacuum have less porosity than those brazed in an Ar flow atmosphere.

2. The braze alloy after brazing is primarily comprised of borides and an $\mathrm{FeNi}_{3}$ matrix with different amounts of alloying elements, especially $\mathrm{B}$ and $\mathrm{Si}$. As the brazing temperature increases, more $\mathrm{Fe}$ atoms are dissolved into the molten braze. Some boron atoms quickly diffuse into 403SS base metal primarily via grain boundary diffusion and form $\mathrm{B}-\mathrm{Cr}-\mathrm{Fe}$ intermetallic precipitates along the grain boundaries of the 403SS close to the joint interface.

3 . High microhardness of the braze results from the existence of a hard metastable phase in the braze for short brazing thermal cycles, e.g., 5 seconds. The hardness of the braze alloy decreases as the brazing time is increased. Based on the wear test results, the wear resistance of the braze alloy with various thermal cycles is much better than that of the 403SS base metal.

4. The shear strength of the joint is around $300 \mathrm{MPa}$ except for specimens brazed in short time periods, e.g., 5 seconds in Ar flow and 30 seconds in vacuum. Fractographs show that the fracture surface mainly consists of brittle fractures and a few sliding facets with no ductile dimple fractures. 


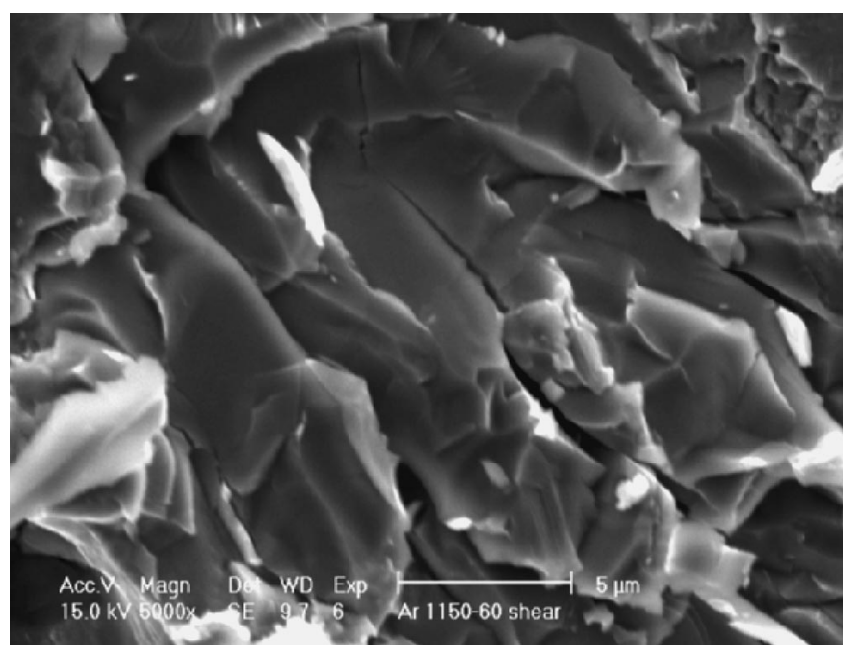

(a)

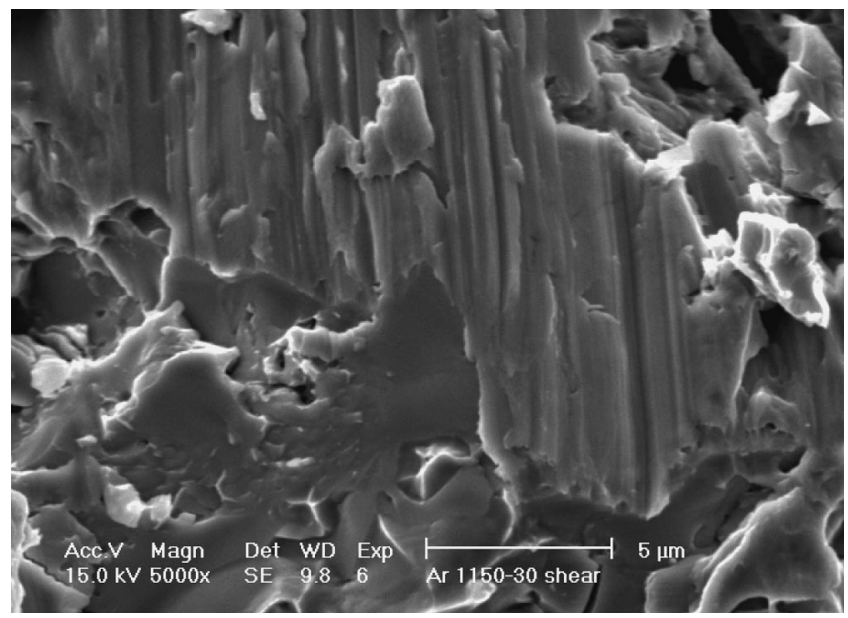

(b)

Fig. 13-The SEM examination of the fracture surface of the braze after shear tests: (a) $1150{ }^{\circ} \mathrm{C} \times 60 \mathrm{~s}$ and $(b) 1150{ }^{\circ} \mathrm{C} \times 30 \mathrm{~s}$.

\section{ACKNOWLEDGMENTS}

The authors gratefully acknowledge the financial support from both the Taiwan Power Company (TPC) and the National Science Council (NSC), Republic of China, under Grant Nos. NSC 89-TPC-7-259-001 and NSC 89-2216E002-002. The EPMA analysis by Shu-Yueh Tsai, NSC Instrument Center, is also gratefully acknowledged.

\section{REFERENCES}

1. M.C. Balmforth and J.C. Lippold: Weld. J., 1998, vol. 77, pp. 1s-7s.

2. R.B. Corbit and S.M. French: Weld. J., 1997, vol. 76, pp. 51-55.

3. D. Armstrong: Weld. World, 1993, vol. 31, pp. 426-27.

4. C.E. Chang: Trans. Geothermal Res., 1989, vol. 13, pp. 569-74.
5. M.K. Lee: J. Nucl. Mater, 1998, vol. 254, pp. 42-48.

6. J.S. Dubey: J. Nucl. Mater., 1998, vol. 254, pp. 271-74.

7. P.R. Sreenivasan, S.K. Ray, S.L. Mannan, and P. Rodriguez: J. Nucl. Mater, 1996, vol. 228, pp. 338-45.

8. Y. Fu, A.W. Batchelor, N.L. Loh, and K.W. Tan: Wear, 1998, vol. 219, pp. 169-76.

9. C.V. Cooper, K. Marchev, and B.C. Giessen: Surf. Coat. Technol., 1998, vol. 99, pp. 229-33.

10. B.H. Olesen, R. Avci, and Z. Lewandowski: Corr. Sci., 2000, vol. 42, pp. 211-27.

11. J. Vollmar and E. Roeder: Int. J. Fatigue, 1996, vol. 18, p. 422.

12. R. Li and M.G.S. Ferreira: Corr. Sci., 1996, vol. 38, pp. 317-27.

13. E. Stagno, M.R. Pinasco, M.G. Ienco, G. Palombarini, and G.F. Bocchini: J. Alloy Compounds, 1997, vol. 247, pp. 172-79.

14. V. Shanov and W. Tabakoff: Surf. Coat. Technol., 1996, vol. 86, pp. 88-93.

15. H.M. Shalaby, J.A. Begley, and D.D. Macdonald: Br. Corr. J., 1994, vol. 29, pp. 43-52.

16. J.S. Dubey, S.L. Wadekar, and J.K. Chakravartty: J. Nucl. Mater, 1998, vol. 254, pp. 271-74.

17. J.G. Gonzalez and Rodriguez: Mater. Lett., 2000, vol. 43, pp. 208-14.

18. B. Miao, D.C. Northwood, L.C. Lim, and M.A. Lai: Mater. Sci. Eng. A-Struct., 1993, vol. 171, pp. 21-33.

19. H.M. Shalaby, J.A. Begley, and D.D. Macdonald: Corrosion, 1996, vol. 52, pp. 262-74

20. L. Albertin, P.K. Liaw, M.G. Burke, and R.L. Frohlich: Scripta Mater, 1991, vol. 25, pp. 2445-50.

21. W.R. Oates and A.M. Saitta: Welding Handbook Volume 4, American Welding Society, Miami, FL, 1998, pp. 233-332.

22. D.L. Olson, T.A. Siewert, S. Liu, and G.R. Edwards: ASM Handbook vol. 6, Welding, Brazing, and Soldering, ASM INTERNATIONAL, Materials Park, OH, 1993, pp. 431-55.

23. D.N. French: Metallurgical Failures in Fossil Fired Boilers, John Wiley \& Sons, Inc., New York, NY, 1993, pp. 242-76.

24. S.J. Lee, S.K. Wu, and R.Y. Lin: Acta Mater., 1998, vol. 46, pp. 1283-95.

25. T.Y. Yang, S.K. Wu, and R.K. Shiue: Intermetallics, 2001, vol. 9, pp. 341-47.

26. S.J. Lee and S.K. Wu: Intermetallics, 1999, vol. 7, pp. 11-21.

27. R.K. Shiue, S.K. Wu, J.M. O, and J.Y. Wang: Metall. Mater. Trans. A, 2000, vol. 31A, pp. 2527-36.

28. M. Schwartz: Brazing: For the Engineering Technologist, Chapman \& Hall, New York, NY, 1995, pp. 8-55.

29. G. Humpston and D.M. Jacobson: Principles of Soldering and Brazing, ASM INTERNATIONAL, Materials Park, OH, 1993, pp. 71-110.

30. M. Roulin, J.W. Luster, G. Karadeniz, and A. Mortensen: Weld. J., 1999, vol. 78, pp. 151s-55s.

31. R.E. Lee: Scanning Electron Microscopy and X-Ray Microanalysis, Prentice Hall, New York, NY, 1993, pp. 130-4.

32. P. Villars, A. Prince, and H. Okamoto: Handbook of Ternary Alloy Phase Diagrams, ASM INTERNATIONAL, Metals Park, OH, 1995, pp. 5508-13.

33. A. Rabinkin, E. Wenski, and A. Ribaudo: Weld. J., 1998, vol. 77, pp. 66s-75s.

34. A. Rabinkin, E. Wenski, and A. Ribaudo: Weld. World, 1998, vol. 41, pp. 466-78.

35. X. Wu, R.S. Chandel, S.H. Pheow, and H. Li: Mater. Sci. Eng. AStruct., 2000, vol. A288, pp. 84-90.

36. S.K. Tung, L.C. Lim, and M.O. Lai: Scripta Mater, 1996, vol. 34, pp. 763-69.

37. P.J. Blau: ASM Handbook, vol. 18, Friction, Lubrication, and Wear Technology, ASM INTERNATIONAL, Materials Park, OH, 1992, pp. 184-90.

38. H. Chandler: Heat Treater's Guide: Practices and Procedures for Irons and Steels, ASM INTERNATIONAL, Metals Park, OH, 1995, pp. 763-65. 